\title{
Bank Credit And Agricultural Output In South Africa: Cointegration, Short Run Dynamics And Causality
}

Joseph Chisasa, University of South Africa, South Africa

Daniel Makina, University of South Africa, South Africa

\begin{abstract}
In this paper we investigate the dynamic relationship between bank credit and agricultural output in South Africa using time series data from 1970 to 2011. Using the Johansen cointegration test, we observe bank credit and agricultural output to be cointegrated. In the long run we find credit and capital formation to have significant positive impact on agricultural output. Employing an $E C M$, we find that, in the short run, bank credit has a negative impact on agricultural output reflecting the uncertainties of institutional credit in South Africa. However, the ECM coefficient shows that agricultural GDP rapidly adjusts to short term disturbances indicating that there is no room for tardiness in the agricultural sector. The absence of institutional credit will be immediately replaced by availability of other credit facilities from non-institutional sources so that there is no room for possible non-application of intermediate inputs. Conventional Granger causality tests show uni-directional causality from (1) bank credit to agricultural output growth; (2) agricultural output to capital formation; (3) agricultural output to labour; (4) capital formation to credit; (5) capital formation to labour, and a bi-directional causality between credit and labour. Noteworthy is that for the agricultural sector the direction of causality is from finance to growth, i.e., supply-leading, whereas at the macroeconomic level the direction of causality is from economic growth to finance, i.e., demand-leading.
\end{abstract}

Keywords: Bank Credit; Agricultural Output; Granger Causality; Cointegration; ECM; South Africa

\section{INTRODUCTION}

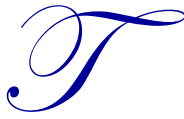

he debate pertaining the relationship between bank credit and agricultural output has been a subject of discussion in recent decades (Carter, 1989; Iqbal et al., 2003) and increasingly so in recent years (Das et al, 2009 and Kumar et al., 2010). The main emphasis of this debate has centred on the impact of institutional credit on growth in agricultural output. Several empirical studies have adopted the Cobb-Douglas (1928) production function to estimate agricultural output function (Enoma, 2010; Sial et al., 2011; Chisasa and Makina, 2013). These studies have largely found credit to have a positive impact on agricultural output.

However, the traditional Cobb-Douglas production function has been observed to portray weaknesses (Tan, 2008; Temple, 2010) which motivate further analysis of the relationship between bank credit and agricultural output. For instance Tan (2008) argues that Cobb and Douglas (1928) were influenced by statistical evidence that appeared to show that labour and capital shares of total output were constant over time in developed countries. However, there is doubt as to whether this constancy exists over time. Furthermore, the standard Cobb-Douglas model does not take account of the uncertainty under which farmers operate so that some researchers have modified it by employing the stochastic production frontier approach suggested by Battese (1992).

At macro level, there are divergent views on the issue of causality regarding the finance-growth nexus. Studies have attempted to answer the empirical question: Does finance lead growth or vice versa? The direction of causality has varied among countries. Studies by Yucel (2009), Adamopoulos (2010) and Dritsakis and 
Adamopoulos (2004) for Turkey, Ireland and Greece respectively have observed finance to Granger cause growth whereas empirical studies in South Africa have observed growth to Granger cause finance (Odhiambo, 2010). On the other hand, there have been studies in China and Kenya that have observed a bi-directional causality between finance and economic growth (Shan and Jianhong, 2006; Wolde-Rufael, 2009; respectively). Most recently, in a sample of ten countries, six from the OECD region and four from the MENA countries, Rachdi and Mbarek (2011) found conflicting relationships between financial development and economic growth. Using the error correction model approach, empirical results revealed that causality is bi-directional for the OECD countries and unidirectional for the MENA countries, i.e., economic growth stimulates financial development. Similar results as obtaining in MENA countries were observed by Akinlo and Egbetunde (2010:17) in Kenya, Chad, South Africa, Sierra Leone and Swaziland.

Further evidence is provided by Caporate et al. (2009) in which the relationship between financial development and economic growth was examined in ten new European Union countries. It was reported that these countries' contribution to economic growth was limited owing to a lack of financial depth. It was also observed that more efficient banking sectors accelerated growth suggesting unidirectional causality flowing from financial development to economic growth and not vice versa. Studies by Arestis et al. (2010) for Greece, India, South Korea, the Philippines, South Africa and Taiwan have observed that financial structure influences economic growth. On the other hand, Taha et al. (2013) analysed the impact of banking intermediation on the economic growth in ten countries in the MENA region and observed a negative correlation between all variables of banking intermediation and economic growth. Similar results obtained for southern Mediterranean countries (Ayadi et al., 2013).

A second empirical question is whether finance and economic growth are cointegrated so that a short run and a long run relationship between the two could be estimated. At a macro level, country level empirical evidence is abound on the long run and short run relationship between bank credit and economic growth and results are mixed. For instance, in Ireland, Adamopoulos (2010) found financial development and economic growth to be cointegrated. The error correction model confirmed the short run relationship. In Ethiopia, Ramakrishna and Rao (2010) found no long run relationship between savings and investment in Ethiopia. Aye (2013) found no long run equilibrium relationship between finance, growth and poverty in Nigeria. However, a short-run causality from growth to finance was observed. Also evidence of causality from poverty to financial deepening conditional on growth was observed.

Within the context of the agricultural sector, several studies on the link between finance and growth have been carried out and reported different results. Izhar and Tariq (2009) examined this relationship for India by estimating the Cobb-Douglas production function. The authors argue that institutional credit has a significant aggregate impact on agricultural production. In Pakistan, Bashir et al., (2010) and Sial et al., (2011) all estimated the Cobb-Douglas production function using multiple regression of the Ordinary Least Squares (OLS) method and observed credit to have a positive influence on agricultural output. Similar results were obtained by Obilor (2013) in Nigeria. None of these studies investigated whether credit and agricultural output are cointegrated in the long run.

This paper contributes to the existing body of literature by focusing on the finance-growth nexus at sectoral level. It seeks to establish the causal relationship between the supply of credit to the agricultural sector and agricultural output as well as investigating whether the two are cointegrated and have a short-run relationship. This article is the first one for South Africa with previous studies either having focused on the credit constraints facing the agricultural sector, particularly smallholder farmers (Lahiff and Cousins, 2005; Chisasa and Makina, 2012) or examined the relationship between credit and agricultural output (Wynne and Lyne, 2003; Chisasa and Makina, 2013).

The rest of the paper proceeds as follows. Section 2 presents literature review. Section 3 discusses the data and methodology. Section 4 presents results. Section 5 concludes. 


\section{LITERATURE REVIEW}

In the literature there are mixed results on the link between credit and agricultural output growth. Some authors argue that credit leads to growth in agricultural output. Others view growth as one of the factors that influence credit supply, thus growth leads and credit follows. Using the OLS method, Ammani (2012) investigated the effect of credit on agriculture in Nigeria; it was observed that formal credit is positively and significantly related to the productivity of crops, livestock and fishing sectors. However, this study did not examine the long run and short run relationship between credit and agricultural output.

Sidhu et al. (2008) used a simultaneous equation model to estimate the contribution of institutional credit towards the use of production inputs, private investments and agricultural growth in Punjab, India. Results showed that the relationship between the use of variable inputs and credit disbursement is highly significant suggesting that agricultural output growth is affected via access to production inputs.

Rahman et al. (2011) assessed the relationship between agricultural credit and farm production in Bangladesh. Although agricultural credit and production revealed a strong positive correlation at $1 \%$ level, it was argued that both the allocation of credit to agriculture and the target output attainment were less satisfactory. Specifically, food grain production was highly correlated (0.938) with agricultural credit disbursement and statistically significant at $1 \%$ level. Asghar and Chughtai (2012) reported similar observations from survey data in Pakistan. Again, these studies have shortcomings in that they did not examine long run and short run relationships.

Sial et al. (2011) used the Johansen and Juselius cointegration and Granger-causality tests to explore the long-run equilibrium relationship and the possible direction of causality between institutional agricultural credit, labour, cropping intensity, water availability and output. Results revealed unidirectional causality from credit to agricultural production. Cointegration results showed the presence of a long run relationship among agricultural gross domestic product, availability of water, agricultural credit, agricultural labour force and cropped area.

Simsir (2012) analysed the relationship between credit growth and agricultural growth in the long run for Turkey. Credit was observed to have a direct effect on agricultural income and employment. Using linear regression, Simsir (2012:362) identified a positive correlation between agricultural income and agricultural loans. Further analysis was conducted using Granger-causality test and the relationship between credit and agricultural output was found to be significant at $95 \%$ confidence level. In this instance a unidirectional causal relationship was observed to flow from credit to real agricultural income. Long run and short run effects were not established.

Unlike Sial et al. (2011), Shabbaz et al. (2013) used the ARDL bounds testing approach to cointegration to examine the relationship between financial development and agricultural growth. The vector error correction model was applied to test long run relationship. Three cointegrating vectors were found and the hypothesis of no cointegration was rejected, thus confirming the presence of a long run relationship between agriculture growth, financial development and labour. However, the authors did not test for the short run effect from the ECM. Rather, Shabbaz et al. (2013:722) applied the vector error correction method (VECM) Granger causality test to detect the direction of causality. Overall results depicted a bidirectional causal relationship between agriculture growth and financial development. Agricultural growth was found to Granger-cause capital and labour significantly.

By and large, studies have not endeavoured to establish the short run impact of agricultural credit on output. They are generally limited in establishing the long run relationship between credit and agricultural output and presenting a research gap in this respect. In studies done at macro level on the finance-growth nexus, long run and short run effects were examined. Ghirmay (2004) examined sub-Saharan African countries and results of the cointegration analysis provided evidence of the existence of a long run relationship between financial development and economic growth among 12 of the 13 countries. The author argues that African countries can accelerate their economic growth by improving their financial systems. However, Ghirmay did not investigate the short run relationship. A subsequent study of panels of 24 sub-Saharan countries by Acaravci et al. (2009) found no long-run relationship between growth of real GDP per capita and domestic credit. When using the panel GMM estimation for causality, the authors observed a bi-directional causal relationship between the growth of real GDP per capita and the domestic credit. 
A study by Dritsakis and Adamopoulos (2004) examined the causal relationship between the degree of openness of the economy, financial development and economic growth in Greece. Using a trivariate vector autoregressive model (VAR), they found that the three variables co-trend indicating the presence of a long-run relationship. Recently, Sunde (2013) carried out cointegration tests for Namibia using the trace and maximum eigenvalue methods. All five variables in the model (real GDP, real GDP per capita as proxies for economic growth and the level of credit to the private sector by financial intermediaries and M2 as a percentage of GDP as proxies for financial development) were found not to be cointegrated.

\section{DATA AND METHODOLOGY}

\subsection{Data}

Time series data for agricultural output, proxied by agricultural gross domestic product (AGDP), rainfall, labour, credit and capital formation for the period 1970 to 2011 was used in this study. Data was obtained from the annual reports of the Department of Agriculture, Forestry and Fisheries (DAFF, 2012). As it is a precondition for time series data to be stationary before conducting Granger causality tests, unit root tests were carried out using the Augmented Dickey-Fuller (ADF) and Phillips and Perron (PP) tests.

\subsection{Methodology}

\subsubsection{Unit Root Tests}

Dickey and Fuller $(1979,1981)$ provide a method of determining the order of integration for individual series, viz.: ADF tests. The model is estimated with a time trend so that for a given variable Y, one estimates the following regression:

$$
\Delta \mathrm{Y}_{\mathrm{t}}=\boldsymbol{\omega}_{0}+\boldsymbol{\omega}_{\mathrm{i}} \mathrm{t}+(\rho-1) \mathrm{Y}_{\mathrm{t}-1}+\sum_{\mathrm{i}=2}^{\mathrm{n}} \varpi_{\mathrm{i}}^{\Delta} \mathrm{Y}_{\mathrm{t}-\mathrm{i}+1}+\varepsilon_{\mathrm{t}}
$$

Equation [1] tests for the null hypothesis of a random walk or non-stationarity against a trend stationary alternative. For a given series, if the estimate of $\rho$ is not significantly different from unity, then the null hypothesis of a random walk cannot be rejected. The Phillips and Perron (1988) PP test is similar to the ADF test but incorporates an automatic correction to the DF procedure for autocorrelated residuals.

Since the objective is to test the long-run and short-run relationship between credit and agricultural output using time series data, it is a precondition of the cointegration test for the data series to be integrated of the order of 1 , that is, I(1) in levels.

\subsubsection{Cointegration Technique}

The presence of a long run relationship among the variables is tested using the Johansen and Juselius (1990) cointegration method on the variables which are found to be integrated of the order of one, viz.: agricultural GDP (Lagdp), rainfall (Lrainfall), capital formation (Lcapform), labour (Llabour) and credit (Lcredit). When applying the cointegration approach, the first step is to select the optimum lag length which was set at three.

The long run relationship is estimated with the log-transformed agricultural output as the dependent variable as follows:

LAGDP $=\beta_{0}+\beta_{1}$ LCAPFORM $+\beta_{2}$ LCREDIT $+\beta_{3}$ LLABOUR $+\beta_{4}$ LRAINFALL $+\varepsilon_{\mathrm{t}}$.

With a sample spanning the period 1970 - 2011, a total of 42 observations after adjustments are included in the analysis. 


\subsubsection{Error Correction Model (ECM)}

After determining the cointegration of variables, a VAR model incorporating an error correction mechanism (ECM) is estimated. A short-run relationship accounting for the three-period lag is conducted using the equation with differenced variables as below in which the ECM is lagged once.

$\Delta$ lagdp $=\mathrm{c}+\beta_{1} \Delta \operatorname{lagdp}(-1)+\beta_{2} \mathrm{~d} \Delta \operatorname{lagdp}(-2)+\beta_{3} \Delta \operatorname{lagdp}(-3)+\beta_{4} \Delta$ lcapform $+\beta_{5} \Delta \operatorname{lcapform}(-1)+\beta_{6} \Delta \operatorname{lcapform}(-2)+$ $\beta_{7} \Delta$ lagdp(-3) $+\beta_{8} \Delta$ lcredit $+\beta_{9} \Delta$ lcredit(-1) $+\beta_{10} \Delta$ lcredit(-2) $+\beta_{11} \Delta$ lcredit(-3) $+\beta_{12}$ d $\Delta$ llabour $+\beta_{13} \Delta$ llabour(-1) + $\beta_{14} \Delta$ llabour(-2) $+\beta_{15} \Delta$ llabour(-3) $+\beta_{16} \Delta$ lrainfall $+\beta_{17} \Delta$ lrainfall(-1) $+\beta_{18} \Delta$ lrainfall(-2) $+\beta_{19} \Delta$ lrainfall(-3) + $\beta_{20} \operatorname{ECM}(-1)+e_{t}$

The Hendry's (1986) general-to-specific modelling method is employed for the parsimonious re-estimation of the basic model in equation [3] to sequentially drop the lagged variables with insignificant coefficients until a preferred model is obtained for the interpretation of the short run dynamics. The coefficient of ECM which is expected to be negative measures the speed of adjustment of the model back to long-run equilibrium after disequilibrium which occurs in response to shocks (Ahmad, 2011).

\subsubsection{Granger Causality Estimation Model}

The conventional causality test is conducted to explore the transmission mechanism between bank credit and agricultural output and other explanatory variables of output. Thus within the bank credit-agricultural output context, the Engle and Granger (1987) two step procedure is investigated using the following equations 4 and 5:

$\operatorname{AGDP}_{\mathrm{t}}=\mathrm{a}+\sum_{j=1}^{N} n_{j}$ Credit $_{t-j}+\sum_{j=1}^{N} y_{j} A G D P_{t-j}+\mu_{t}$
Credit $_{\mathrm{t}}=\mathrm{c}+\sum_{j=1}^{N} \alpha_{j} A G D P_{t-j}+\sum_{j=1}^{N} \beta_{j}$ Credit $_{t-j}+\mu_{t}$

Where: AGDP $=$ Agricultural gross domestic product

Credit $\quad=$ Bank credit to the agricultural sector

$\mathrm{t} \quad=$ time period $(1970-2011)$.

The error terms $\mu$ are assumed to be uncorrelated.

The null hypotheses to be tested are:

$\mathrm{H}_{1}: \mathrm{n}_{\mathrm{j}}=0, \mathrm{j}=1,2,3 \ldots \ldots \ldots . \mathrm{N}$ meaning that bank credit does not Granger cause agricultural output (AGDP). $\mathrm{H}_{2}: \alpha_{\mathrm{j}}=0, \mathrm{j}=1,2,3 \ldots \ldots \ldots \mathrm{N}$ meaning that AGDP does not Granger cause bank credit.

If the first hypothesis is rejected, it means that bank credit Granger causes AGDP. Rejection of the second hypothesis would show that the causality runs from AGDP to bank credit. If none of the hypothesis is rejected, it would mean that bank credit does not Granger cause AGDP and AGDP also does not Granger cause bank credit indicating that the two variables are independent of each other. If all the hypotheses are rejected, it means there is bidirectional causality between bank credit and AGDP. Pairwise Granger causality tests among factors influencing AGDP are also performed. 


\section{RESULTS AND DISCUSSION}

\subsection{Unit Root Results}

The unit root test results are reported in Table 1 below. Both the ADF and PP tests fail to reject the null hypothesis of the presence of a unit root for all the data series. In levels, all variables were integrated of order one or I(1). Thus the null hypothesis of stationarity was rejected for all the five series. The series became stationary or I(0) in first differences. This paved way for tests for the long-run relationship between bank credit and agricultural output using the Johansen-Juselius cointegration test.

Table 1: Results of unit root tests

\begin{tabular}{|c|c|c|c|c|c|c|c|c|}
\hline \multirow[b]{2}{*}{ Variable } & \multirow[b]{2}{*}{$\begin{array}{l}\text { Level with } \\
\text { Intercept }\end{array}$} & \multicolumn{2}{|c|}{ Augmented Dickey Fuller } & \multirow[b]{2}{*}{$\begin{array}{c}\text { Order of } \\
\text { Integration }\end{array}$} & \multirow[b]{2}{*}{$\begin{array}{l}\text { Level with } \\
\text { Intercept }\end{array}$} & \multicolumn{2}{|c|}{ Phillips \& Perron } & \multirow[b]{2}{*}{$\begin{array}{c}\text { Order of } \\
\text { Integration }\end{array}$} \\
\hline & & $\begin{array}{c}\text { Order of } \\
\text { Integration }\end{array}$ & $\begin{array}{l}\text { Ist Difference } \\
\text { with Intercept }\end{array}$ & & & $\begin{array}{c}\text { Order of } \\
\text { Integration }\end{array}$ & $\begin{array}{l}\text { Ist Difference } \\
\text { with Intercept }\end{array}$ & \\
\hline LAGDP & -1.8030 & $\mathrm{I}(1)$ & $-6.0807^{* * *}$ & $\mathrm{I}(0)$ & $-4.7255^{*}$ & $\mathrm{I}(0)$ & $-6.6847^{* * *}$ & $\mathrm{I}(0)$ \\
\hline LRAINFALL & -1.2017 & $\mathrm{I}(1)$ & $-9.1026^{* * *}$ & $\mathrm{I}(0)$ & -2.4395 & $\mathrm{I}(1)$ & $-9.0840^{* * *}$ & $\mathrm{I}(0)$ \\
\hline LCREDIT & -1.0458 & $\mathrm{I}(1)$ & $-3.8213^{* * *}$ & $\mathrm{I}(0)$ & -1.4349 & $\mathrm{I}(1)$ & $-3.0228^{* *}$ & $\mathrm{I}(0)$ \\
\hline LLABOUR & -1.9335 & $\mathrm{I}(1)$ & $-6.4241^{* * *}$ & $\mathrm{I}(0)$ & -2.1976 & $\mathrm{I}(1)$ & $-6.1396^{* * *}$ & $\mathrm{I}(0)$ \\
\hline LCAPFORM & -2.4661 & $\mathrm{I}(1)$ & $-6.5084^{* * *}$ & $\mathrm{I}(0)$ & -2.1537 & $\mathrm{I}(1)$ & $-4.7498^{* * *}$ & $\mathrm{I}(0)$ \\
\hline
\end{tabular}

\subsection{Cointegration Results}

The Johansen Trace cointegration test shows that there are three integrating equations at the $95 \%$ confidence level $(\mathrm{p}$-value $=0.05)$ suggesting that credit, rainfall, labour, capital formation and agricultural output are cointegrated. Both the Trace Statistic and the Max-Eigen Statistic are higher than the Eigenvalue and thus confirming that in the long run, bank credit, labour, capital formation, rainfall and agricultural output are cointegrated. The results are presented in Tables 2 and 3 below:

Table 2: Trace Statistics

\begin{tabular}{lcc}
\hline Unrestricted Cointegration Rank Test (Trace) & & Trace Statistic \\
\hline Hypothesised No. Of CEs & Eigenvalue & 127.0105 \\
\hline None $^{*}$ & 0.784945 & 68.60969 \\
At most ${ }^{*}$ & 0.602603 & 33.54259 \\
At most ${ }^{*}$ & 0.437802 & 11.65837 \\
At most 3 & 0.230796 & 1.687203 \\
At most 4 & 0.043429 &
\end{tabular}

Table 3: Max-Eigen Statistics

\begin{tabular}{lcc}
\hline Hypothesised No. Of CEs & Eigenvalue & Max-Eigen Statistic \\
\hline None $^{*}$ & 0.784945 & 58.40078 \\
At most $1^{*}$ & 0.602603 & 35.06710 \\
At most 2* & 0.437802 & 21.88422 \\
At most 3 & 0.230796 & 9.971166 \\
At most 4 & 0.043429 & 1.687203 \\
\hline
\end{tabular}

Max-eigenvalue test indicates three cointegrating equations at the 0.05 level

Results of the long-run relationship between credit and agricultural output are presented as Table 4 below. 
Table 4: Estimated the Long-Run Equation

\begin{tabular}{|c|c|}
\hline Independent Variables & $\begin{array}{l}\text { Coefficient } \\
\text { (t-statistic) }\end{array}$ \\
\hline Constant & $\begin{array}{c}0.416 \\
(0.282) \\
\end{array}$ \\
\hline LCAPFORM & $\begin{array}{c}0.626^{* * *} \\
(10.20)\end{array}$ \\
\hline LCREDIT & $\begin{array}{c}0.490 * * * \\
(8.35)\end{array}$ \\
\hline LLABOUR & $\begin{array}{l}0.201 \\
(1.28)\end{array}$ \\
\hline LRAINFALL & $\begin{array}{c}-0.300 * * * \\
(-3.80)\end{array}$ \\
\hline No. of Observations & 42 \\
\hline R-squared & 0.99 \\
\hline Adjusted R-squared & 0.99 \\
\hline S.E. of regression & 0.12 \\
\hline Log Likelihood & 31.87 \\
\hline F-statistic & $1214.36[0.000]$ \\
\hline Durbin-Watson statistic & 0.96 \\
\hline
\end{tabular}

Results show that capital formation and credit influence agricultural output positively at the $1 \%$ level of significance. A $1 \%$ increase in capital investments (capital formation) will result in a $0.63 \%$ increase in agricultural output. These results support the argument by Rajni (2013) that capital formation is the core of economic development and development is not possible without adequate capital resources. Similarly, a $1 \%$ increase in bank credit will result in a $0.49 \%$ increase in agricultural output holding other factors in the model constant. Similar results were obtained by Bashir (2010), Ahmad (2011) and Chisasa and Makina (2013) for South Africa using the Cobb-Douglas model.

Rainfall is observed to have a negative and significant relationship with agricultural output at $1 \%$ level of significance. Thus a $1 \%$ increase in rainfall will result in a $0.30 \%$ decline in agricultural output. The impact of rainfall on agricultural output can be positive or negative. For example, during drought periods, crops wither before maturity. In times of excess rains, which normally result in floods and waterlogging, the yields are poor (Development Bank of Southern Africa, 2010). South Africa is characterised by a semi-arid climate and therefore supplements its water requirements for agricultural use through irrigation (Fanadzo et al., 2010).

While the low Durban-Watson statistic and the high R-squared suggest serial correlation and nonstationarity of variables, the long run results largely resemble those of Chisasa and Makina (2013) who utilised differenced variables and corrected for serial correlation for the same set of data. However, the purpose of estimating the long run equation is to enable computing of the error correction term to be used as an input variable for the short run ECM that utilised differenced variables. 


\subsection{ECM Short Run Results}

The results of the parsimonious regression analysis are presented in Table 5 below.

Table 5: ECM regression results after parsimonious exercise

\begin{tabular}{|c|c|}
\hline Independent variables & $\begin{array}{l}\text { Coefficient } \\
\text { (t-statistic) }\end{array}$ \\
\hline Constant & $\begin{array}{c}0.112 * * * \\
(3.89)\end{array}$ \\
\hline$\Delta \operatorname{LAGDP}(-3)$ & $\begin{array}{c}-0.313 * * \\
(-2.21)\end{array}$ \\
\hline$\Delta \operatorname{LAGDP}(-4)$ & $\begin{array}{l}-0.157 \\
(-1.64)\end{array}$ \\
\hline$\triangle \mathrm{LCAPFORM}$ & $\begin{array}{c}0.613 * * * \\
(8.15)\end{array}$ \\
\hline$\triangle \mathrm{LCAPFORM}(-1)$ & $\begin{array}{c}-0.182 * * * \\
(-2.89)\end{array}$ \\
\hline$\Delta$ LCAPFORM(-2) & $\begin{array}{l}-0.073 \\
(-1.29) \\
\end{array}$ \\
\hline$\Delta$ LCAPFORM(-3) & $\begin{array}{c}0.182 * * \\
(2.13) \\
\end{array}$ \\
\hline$\Delta$ LCREDIT(-3) & $\begin{array}{c}-0.318^{*} \\
(-1.85) \\
\end{array}$ \\
\hline$\Delta$ LLABOUR(-1) & $\begin{array}{c}-0.250^{*} \\
(-1.83)\end{array}$ \\
\hline$\triangle$ LRAINFALL & $\begin{array}{c}-0.233 * * * \\
(-3.32)\end{array}$ \\
\hline $\operatorname{ECM}(-1)$ & $\begin{array}{c}-0.661 * * * \\
(-5.18)\end{array}$ \\
\hline $\begin{array}{l}\text { R-squared } \\
\text { Adjusted R-squared } \\
\text { S.E. of regression } \\
\text { Log Likelihood } \\
\text { F-statistic } \\
\text { Durbin-Watson statistic }\end{array}$ & $\begin{array}{c}0.81 \\
0.73 \\
0.06 \\
56.78 \\
10.91[0.000] \\
1.62 \\
\end{array}$ \\
\hline
\end{tabular}

$* * *, * *, *$ Respectively significant at $1 \%, 5 \%$ and $10 \%$ level

The ECM(-1) term has a significantly negative coefficient meaning that agricultural GDP rapidly adjusts to short term disturbances in the sector. There is no room for tardiness in the agricultural sector. Disturbances occasioned by poor or low rainfall will be rapidly compensated for by the application of irrigation facility. The absence of institutional credit will be immediately replaced by availability of other credit facilities from noninstitutional sources. There is no room for possible non-application of intermediate inputs such as seeds, fertilizers, chemicals, harvesting facilities, etc.

In the short run current capital formation is associated with a positive significant increase in agricultural GDP. On the other hand, capital formation in the previous two years is observed to impact negatively on agricultural GDP. These results are consistent with the observation by Wolf (1991:566) who postulates that new capital is more productive than old capital per unit of expenditure, a phenomenon called the "vintage effect." Previous employments of capital amount to unutilized capital in the agricultural sector and as such contribute negatively to agricultural GDP.

Credit in the previous periods has a significant negative impact on agricultural GDP in the short run. In the long run we have observed that credit has a positive impact. Therefore, the negative impact in the short run could be a result of several factors peculiar to the South African context. First, it could be the result of the short-term nature of credit to farmers whereby banks may require them to repay loans even before harvesting and selling their produce. Thus a mismatch between production and repayment cycles would adversely affect output. Second, it could be the result of high interest rates charged on loans to farmers by virtue of sector having a longer production period 
as compared with other sectors. Third, the negative impact in the short run could be the result of the uncertain nature of agricultural output whose risks include, among others, uncertain prices, high input costs, climatic conditions, etc. Notwithstanding the negative impact in the short term, the adjustment process to positive equilibrium position is rapid and evidenced with a highly significant negative ECM (-1).

Labour in the previous period is negatively associated with agricultural GDP in the short term. This is expected in the South African context because of inflexible labour laws characterised by high unionisation that have adverse effect on productivity.

The short run results appear to be unique for the South African agricultural sector. To our knowledge the few studies that have attempted to investigate the short run effect on the sector were undertaken in Pakistan. One study by Sial et al. (2011) that utilised time series data from 1973-2009 (37 years) observed no significant short run effects. Another study by Shahbaz et al. (2011) that utilised time series data from 1971-2011 (41 years) observed significant positive effects with respect to current capital formation and credit in the previous period and significant negative effect with respect to labour. However, unlike in South Africa where deviations from equilibrium are rapidly corrected (by $65 \%$ per year), in Pakistan deviations in the short run towards the long run are corrected by $11.86 \%$ per year. The researchers attribute this slow adjustment to equilibrium to the high cost of agricultural production in Pakistan.

\subsection{Granger Causality Results}

Table 6 below gives results of the pairwise conventional Granger causality tests among the variables AGDP, bank credit, capital formation and labour.

Table 6: Pairwise Granger Causality Results

\begin{tabular}{lccccl}
\hline \multicolumn{1}{c}{ Null Hypothesis } & Obs. & Lags & F-Statistic & Probability & Results \\
\hline$\Delta$ LCapform does not Granger cause $\Delta$ LAGDP & 39 & 1 & 1.42641 & 0.2402 & $\mathrm{H}_{0}$ is not rejected \\
$\Delta$ LAGDP does not Granger cause $\Delta$ LCapform & 39 & 1 & 5.35040 & $0.0265^{* *}$ & $\mathrm{H}_{0}$ is rejected \\
$\Delta$ LCredit does not Granger cause $\Delta$ LAGDP & 39 & 1 & 6.46505 & $0.0154^{* *}$ & $\mathrm{H}_{0}$ is rejected \\
$\Delta$ LAGDP does not Granger cause $\Delta$ LCredit & 39 & 1 & 0.01942 & 0.8899 & $\mathrm{H}_{0}$ is not rejected \\
$\Delta$ Llabour does not Granger cause $\Delta$ LAGDP & 39 & 1 & 4.46534 & 0.4995 & $\mathrm{H}_{0}$ is not rejected \\
$\Delta$ LAGDP does not Granger cause $\Delta$ Llabour & 39 & 1 & 7.65170 & $0.0089^{* * *}$ & $\mathrm{H}_{0}$ is rejected \\
$\Delta$ Lcredit does not Granger cause $\Delta$ Lcapform & 39 & 1 & 2.24937 & 0.1424 & $\mathrm{H}_{0}$ is not rejected \\
$\Delta$ Lcapform does not Granger cause DLcredit & 39 & 1 & 4.18942 & $0.0480^{* *}$ & $\mathrm{H}_{0}$ is rejected \\
$\Delta$ Llabour does not Granger cause $\Delta$ Lcredit & 39 & 1 & 4.19920 & $0.0478^{* *}$ & $\mathrm{H}_{0}$ is rejected \\
$\Delta$ Lcredit does not Granger cause $\Delta$ Llabour & 39 & 1 & 3.90529 & $0.0558^{*}$ & $\mathrm{H}_{0}$ is rejected \\
\hline
\end{tabular}

$* * *, * *,{ }^{*}$ Respectively significant at $1 \%, 5 \%$ and $10 \%$ level

The results reveal the presence of unidirectional causality flowing from bank credit to agricultural GDP, thus confirming the a priori expectations. There is no evidence of reverse causality. This means that increasing credit supply to farmers will cause an increase in agricultural production holding other factors constant. These results are consistent with the long-run relationship and those of Sial et al. (2011) for Pakistan. However, for South Africa this result is in conflict with the macroeconomic level results which show a demand-leading relationship, i.e. a unidirectional causality from economic growth to financial development (Odhiambo, 2010). Thus, Granger causality at sectoral level is not necessarily the same as that at macroeconomic level. Also observed are unidirectional causality from (1) AGDP to capital formation; (2) AGDP to labour; (3) capital formation to credit; (4) capital formation to labour; and a bi-directional causality between credit and labour. These results are largely as expected and consistent with those of Simsir (2012) and Ahmad (2011).

\section{CONCLUSION}

Previous studies in South Africa have established that farmers, particularly smallholder farmers are credit constrained. It has been subsequently argued that agricultural output has been adversely affected by inadequate finance. None of these studies have tested the dynamic relationship between credit and agricultural output. 
The Johansen-Juselius cointegration test was performed and confirmed the presence of a long-run relationship between agricultural output, credit, capital formation, rainfall and labour. The results show that there is a positive and significant relationship between bank credit, capital formation and agricultural output in South Africa. In addition, the paper finds that there is a negative and significant relationship between rainfall and agricultural output.

Using the error correction mechanism, the empirical results of this study show that, in the short term, capital formation has a positive and significant influence on agricultural output. The estimated coefficient of the error correction term is high and significantly negative showing a rapid adjustment to equilibrium. Thus while credit might have a negative impact on agricultural output in the short-term, the adjustment mechanism to the long-run where it has a positive impact is rapid.

Based on the Engle-Granger causality test performed, it was concluded that there is a unidirectional causation flowing from (1) bank credit to agricultural output growth; (2) agricultural output to capital formation; (3) agricultural output to labour; (4) capital formation to credit; (5) capital formation to labour, and a bi-directional causality between credit and labour. Noteworthy is that for the agricultural sector the direction of causality is from finance to growth, i.e., supply-leading, whereas at the macroeconomic level the direction of causality is from economic growth to finance, i.e., demand-leading.

\section{ACKNOWLEDGEMENTS}

The paper is based on an ongoing doctoral research project by the first author entitled: An Empirical Study of the Impact of Bank Credit on Agricultural Output in South Africa. Correspondence should be addressed to Joseph Chisasa at UNISA, Private Box 392, Pretoria 0003, e-mail: Chisaj@unisa.ac.za, Telephone: +27 (12) 4294613.

\section{AUTHOR INFORMATION}

Mr. Joseph Chisasa is a Senior Lecturer in the Department of Finance, Risk Management and Banking of the University of South Africa. He holds a Master of Science Degree in Finance and Investment and a Bachelor of Commerce Degree in Banking (Honours). He is a Certified Associate of the Institute of Bankers of South Africa, Associate Member of the Institute of Bankers of Zimbabwe and an Associate Member of the Institute of Credit Management of South Africa. He has published in the International Business and Economics Research Journal. His research interests are in banking and credit risk management. E-mail: Chisaj@unisa.ac.za.

Dr. Daniel Makina is a Professor of Finance and Banking in the Department of Finance, Risk Management and Banking of the University of South Africa. He has published in recognized national and international journals that include: Applied Financial Economics, Applied Economics, International Business and Economics Research Journal, Journal of Developing Societies, Journal of Accounting and Finance Research, Business Review, African Development Review, African Finance Journal, among others. His research interests are in emerging financial markets, banking and migration issues related to financial development. Address: University of South Africa, PO Box 392, Pretoria 0003, South Africa. E-mail: makind@unisa.ac.za 


\section{REFERENCES}

Adamopoulos, A. (2010). Financial development and economic growth: An empirical analysis for Ireland. International Journal of Economic Sciences and Applied Research, 3(1): 75-88.

Ahmad, N. (2011). Impact of institutional credit on agricultural output: a case study of Pakistan. Theoretical and Applied Economics, XVIII(10)(563):99-120.

Akinlo, A.E. \& Egbetunde, A.E. (2010). Financial development and economic growth: The experience of 10 SubSaharan African countries revisited. The Review of Finance and Banking, 2(1): 17-28.

Ammani, A.A. (2012). An investigation into the relationship between agricultural production and formal credit supply in Nigeria. International Journal of Agriculture and Forestry, 2(1): 46-52.

Arestis, P., Luintel, A.D. \& Luintel, K.B. (2010). Financial structure and economic growth: evidence from time series. Applied Financial Economics, 20: 1479-1492.

Asghar, N. \& Chughtai, M.W. (2012). Impact of agricultural credit on production of wheat crop: A case study of District Faisaland-Pakistan. Administratio, 4(2): 43-51.

Acaravci, S. K., Ozturk, A. \& Acaravci, A. (2009). Financial development and economic growth: Literature survey and empirical evidence from sub-Saharan countries. South African Journal of Economic and Management Sciences, 12(1):11-27.

Ayadi, R. \& Arbak, E. (2013). Financial development, bank efficiency and economic growth across the Mediterranean. MEDPRO Technical Report No. 30/March 2013.

Aye, G.C. (2013). Causality between financial deepening, economic growth and poverty in Nigeria. The Business Management Review, 3(3):1-12.

Bashir, M. K., Mehmood, Y. \& Hassan, S. (2010). Impact of agricultural credit on productivity of wheat crop: Evidence from Lahore, Punjab, Pakistan. Pakistan Journal of Agricultural Science, 47(4):405-409.

Battese, G. E. (1992). Frontier production functions and technical efficiency: A survey of empirical applications in agricultural economics. Agricultural Economics, 7(3): 187-208.

Bernard, O.A. (2009). An empirical analysis of credit supply and agricultural output in Nigeria. [Online] Available from: http://www.scribd.com/doc/23834331/Credit-SS-Agric-Output

Caporale, G.M., Rault, C., Sova, R. \&Sova, A. (2009).Financial development and economic growth: Evidence from ten new EU members. German Institute for Economic Research. Discussion Paper No.940.

Carter, M.R. (1989). The impact of credit on peasant productivity and differentiation in Nicaragua. Journal of Development Economics, 31: 13-36.

Chisasa, J. \& Makina, D. (2013). Bank credit and agricultural output in South Africa: A Cobb-Douglas empirical analysis. International Business and Economics Research Journal, 12(4):387-398.

Cobb, C.W. \& Douglas, P.H. (1928). A theory of production. The American Economic Review, 18(1): 139-165.

Das, A., Senapati, M. \& John, J. (2009). The impact of agricultural credit on agriculture production: An empirical analysis in India. Reserve Bank of India Occasional Papers, 30(2): 75-107.

Development Bank of Southern Africa. 2011 Annual Report. [Online] Available from http://www.dbsa.org [Accessed: 2014-03-03].

Dickey, D and Fuller, W (1979): "Distribution of the Estimators for Autoregressive Time Series with a Unit Root", Journal of the American Statistical Association, 74:427-431.

Dickey, D and Fuller, W (1981): Likelihood Ratio Statistics for Autoregressive Time Series with a Unit Root, Econometrica, 49, 1057-1072.

Dritsakis, N. \& Adamopoulos, A. (2004). Financial development and economic growth in Greece: An empirical investigation with Granger causality analysis. International Economic Journal, 18 (4): 547-559

Engle, R.F. \& Granger, C.W.J. (1987). Co-integration and error correction: Estimation and testing. Econometrica, 55(2): 251-276.

Enoma, A. (2010). Agricultural credit and economic growth in Nigeria: An empirical analysis. Business and Economics Journal, 14: 1-7.

Ghirmay, T. (2004). Financial development and economic growth in Sub-Saharan African countries. African Development Review, 16(3):415-432.

Hendry, D.F. (1986). Econometric modelling with cointegrated variables: An overview. Oxford Bulletin of Economics and Statistics, 48: 201-212.

Iqbal, M., Ahmad, M. \& Abbas, K. (2003). The impact of institutional credit on agricultural production in Pakistan. The Pakistan Development Review, 42(4):469-485. 
Izhar, A. \& Tariq, M. (2009). Impact of institutional credit on aggregate agricultural production in India during post reform period. MPRA Paper No. 17075. [Online] Available at http://mpra.ub.uni-muenchen.de/17075/

Johansen, S. and Juselius, K. (1990). Maximum Likelihood Estimation and Inference on Cointegration - With Application to the Demand for Money. Oxford Bulletin of Economics and Statistics, 52: 169-210.

Kumar, A., Singh, K.M. \& Sinha, S. (2010). Institutional credit to agricultural sector in India: Status, performance and determinants. Agricultural Economics Review, 23: 223-264.

Lahiff, E. \& Cousins, B., 2005. Smallholder agriculture and land reform in South Africa. Institute of Development Studies Bulletin, 36(2): 127-131.

Madhusoodnan, P.R. \& Kumar, H. V. (2008). An empirical verification of cointegration and causality in Indian Stock Markets: a case of BSE and NSE. South Asia Economic Journal, 9(1):159-172.

Obilor, S. I. (2013). The impact of banks' credit to agriculture on agricultural development in Nigeria: An econometric analysis. International Journal of Business, Humanities and Technology, 3(1):85-94.

Odhiambo, N.M. (2010). Finance-investment-growth nexus in South Africa: A dynamic causality linkage. The Journal of Socio-Economics, 38: 320-325.

Phillips, P.C.B. \& Perron, P. (1988). Testing for a unit root in time series regression. Biometrika, 75(2): 335-346.

Rachdi, H. \& Mbarek, H.B. (2011). The causality between financial development and economic growth: Panel data cointegration and GMM system approaches. International Journal of Economics and Finance, 3(1): 143151.

Rahman, M.W., Luo, J. \& Cheng, E. (2011). Policies and performances of agricultural credit in Bangladesh: What is the influence on agricultural production? African Journal of Agricultural Research, 6(31): 6440-6452.

Rajni, P. (2013). Empirical investigation of capital formation by agriculture and industry on industrial productivity in India. Research Journal of Management Sciences, 2(3): 8-11.

Ramakrishna, G. \& Rao, S. V. (2012). The long run relationship between savings and investment in Ethiopia: a cointegration and ECM approach. Developing Country Studies, 2(4):1-7.

Shabbaz, M., Shabbir, M.S. \& Butt, M.S. (2013). Effect of financial development on agricultural growth in Pakistan: New extensions from bounds test to level relationships and Granger causality tests. International Journal of Social Economics, 40(8): 707-728.

Shan J.\& Jianhong Q. (2006). Does development 'lead' economic growth? The case of China. Annals of Economics and Finance, 1:197-216.

Sial, M.H., Awan, M.S. \& Waqas, M. (2011). Institutional credit and agricultural production nexus. MPRA Paper No. 30392. [Online] Available from http://mpra.ub.uni-munichen.de/30392/

Simsir, N.C. (2012). An econometric analysis of the relationships between economic growth and agricultural credits for pro-poor growth in Turkey. International Journal of Social Sciences and Humanity Studies, 4(2): 355364.

South Africa (2010), Department of Agriculture, Forestry and Fisheries, Abstract of agricultural statistics, [Accessed 20 July 2013 (http://www.daff.gov.za).]

Sunde, T. (2013). Financial development and economic growth: empirical evidence from Namibia (1990Q12011Q4). An Online International Monthly Journal, 1(1):53-65.

Taha, Z., Anis, O. \& Hassen, S. (2013). Banking intermediation and economic growth: Some evidence from MENA countries. Advances in Management and Applied Economics, 3(4):51-57.

Tan, B.H. (2008). Cobb-Douglas production function. [Online] Available from: http://docents.fe.unl.pt/ jamador/Macro/cob-douglas.pdf [Downloaded: 2012-07-29].

Temple, J. (2010). Aggregate production functions, growth economics, and the part-time tyranny identity: a reply to Felipe and McCombie. International Review of Economics, 24(6): 685-692.

Wynne, A.T., \& Lyne, M.C. 2003. An empirical analysis of factors affecting the growth of small-scale poultry enterprises in KwaZulu-Natal. Development Southern Africa, vol 20, no 5, 563-577.

Yucel, F. (2009). Causal relationships between financial development, trade openness and economic growth: The case of Turkey. Journal of Social Sciences, 5(1): 33-42. 